\title{
Sobre este número
}

Este número é resultado da reunião de trabalhos submetidos e apresentados no III Congresso Brasileiro de Organização do Espaço (CBOE) e XV Seminário de Pós-Graduação em Geografia da Unesp, campus Rio Claro, que ocorreu nos dias 31 de maio, 2 e 4 de junho de 2021. Os oito artigos que constituem esse número trazem para o debate temas como a piscicultura brasileira, a avaliação das licenciaturas em Geografia a partir do Exame Nacional de Desempenho de Estudantes (ENADE), as conexões entre Geografia e literatura brasileira, as Cataratas do Iguaçu enquanto um geopatrimônio, o turismo sócio familiar prisional em tempos de Covid-19, o financiamento das infraestruturas no Brasil, a atuação das corporações de agrotóxicos e a trajetória dos livros didáticos de Geografia.

O número tem início com o artigo "A piscicultura brasileira pela ótica do desenvolvimento da genética da tilápia: das horizontalidades ao processo de verticalização", de autoria de Maico Eduardo Dias Dias e Edilson Luis Oliveira. Mediante à análise da piscicultura, em especial a tilapicultura brasileira, os autores averiguaram os processos de horizontalidades e verticalidades relacionados ao melhoramento genético da espécie tilápia. Dentre as diversas conclusões, o artigo aponta para um crescente aumento na verticalização no setor, especialmente pela expansão, em território nacional, da empresa de capital global Genomar Genetics Group.

Em seguida, o artigo denominado "Conteúdos culturais-cognitivos versus pedagógico-didático na formação docente em geografia a partir da categorização de questões do currículo avaliado/ENADE (2005-2017)", foi escrito por Jéssica Gomes de Jesus Oliveira e Pedro Wagner Gonçalves. Através de uma análise dos modelos de formação docente propostos por Saviani (2009), discute quais estão presentes na organização curricular dos cursos de licenciatura em Geografia e se as questões das avaliações do ENADE abarcam esses modelos. Com essas investigações, os autores ressaltam que o ENADE, como currículo avaliado, pode ser um fator indutor de maior equilíbrio entre a formação técnico-científica e pedagógica.

O terceiro artigo desta edição, intitulado por "Espaço e subjetividade na Geografia de Dona Benta (1935), de Monteiro Lobato: aportes geográficos e literários", de elaboração de Filipe Rafael Gracioli e João Pedro Pezzato, tem o objetivo de fazer uma análise literária e geográfica, pautada na imaginação criativa e na geograficidade, da obra "Geografia de Dona Benta". De importância única, essa narrativa possui grande relevância entre a juventude de leitores brasileiros até a atualidade.

Quanto ao artigo "Estratégias e atuação das corporações de agrotóxicos e sementes em Mato Grosso: uso corporativo do território e apropriação das rendas do agronegócio", de Ana Flávia Marcondes do Amaral, ele detém o objetivo de compreender quais são os poderes de influência e controle que as corporações exercem no território por meio da comercialização dos sistemas técnicos. Nesse sentido, são discutidas as estratégias da apropriação de renda do agronegócio no estado de Mato Grosso (MT).

Já no Artigo "Mudanças no padrão brasileiro de financiamento à infraestrutura e suas implicações territoriais", o autor Bruno Moreira Riani Costa debate o crescimento do mercado de títulos privados de longo prazo no Brasil e o desmonte dos meios de financiamento público à infraestrutura, com destaque para o papel do BNDES. Ao longo do texto é afirmado que o mercado de capitais poderia ser amadurecido e sofisticado sem haver concomitante corrosão do sistema de financiamento público. Há ênfase, principalmente, para como essas alterações, 
ligadas ao financiamento das infraestruturas no país, ocasionam novos usos do território.

Posteriormente, o autor José Rafael Vilela da Silva, em seu artigo denominado por "O geomito das Cataratas do Iguaçu: o geopatrimônio sob o olhar dos saberes populares e geocientíficos", discute o processo de formação das cataratas a partir de dois aspectos: o olhar mítico advindo das lendas e mitos de origem indígena e o olhar científico desenvolvido a partir dos cientistas, em suas pesquisas, sobre o local. $O$ trabalho traz excelentes reflexões sobre geopatrimônio, geodiversidade e sobre a importância de conciliar as interpretações de ambos os saberes.

O texto nomeado "Turismo sócio familiar prisional em tempos de Covid-19: uma nova perspectiva de visitação", dos autores, João Paulo Bloch e Carlos Henrique Costa da Silva, relata como a suspensão das visitas nas unidades prisionais, devido à pandemia do COVID-19, atinge a economia dos arredores de presídios. É destacado, por exemplo, como que com a retomada das visitas dos familiares nos presídios em São Paulo, é reativado parcialmente o fluxo econômico e turístico relacionado a essa dinâmica.

Por fim, Gabriel Pinto de Bairro e José Vitor Rossi Souza, autores do texto "Uma proposta de periodização para os livros didáticos de Geografia no Brasil", fazem uma análise da produção didática de Geografia no país, investigando um período que abrange os séculos $X X$ e XXI. O artigo possibilita um olhar sobre esse importante instrumento da Geografia escolar, os livros didáticos, por meio da integração de elementos da Pedagogia, da Geografia e da política editorial, o que abre caminhos para novas investigações baseadas nas conexões observadas. 